\title{
Hjertets gudbilledlighed
}

\author{
Af Erik Krebs Jensen
}

\section{Udgangspunktet}

Det er et iøjenfaldende træk ved Grundtvigs salmer, at de udviser en lang række eksempler på variationer over formler, hvor bestemte ord indgår i særlige forbindelser med hinanden. Den kendteste forbindelse er vel »badet og bordet«. Hvis man slår efter, hvor denne sammenstilling findes i salmerne, viser det sig, at "Livs-Ordet« og »Hjerte« næsten altid er knyttet dertil. Ved badet og bordet lyder Livs-Ordet til hjertet. Dette er en formel eller et grundmønster, der varieres i salmer fra 1850. Men det er kun et eksempel blandt mange. Iagttagelsen af sådanne faste strukturer i Grundtvigs salmer er baggrunden for En glemt dimension $i$ Grundtvigs salmer af Chr. Thodberg.

I foråret 1974 blev denne iagttagelse det metodiske udgangspunkt for en øvelse over Grundtvigs salmer på Århus Universitet. Ved at undersøge emner som f.eks. Fadervor, et hyppigt anvendt ord f.eks. hjerte eller et centralt teologisk ord som f.eks. tro i dets "faste " forbindelser samt overhovedet alt, hvad det indgik i sammenhæng med, var det hensigten at nå frem til en forståelse af teksten, som ikke var bestemt af nutidig sprogbrug, men af ordets grundtvigske sammenhæng.

Til dette formål er salmerne særligt velegnede. I prædikener og andre tekster udtrykker Grundtvig sig oftest meget polemisk. I salmerne tilstræber han derimod en klar fremstilling af menneskets fortvivlelse og oprejsning. Som poet formidler han sine billedsyner af det guddommelige gennem billedsproget, så hverdagsmennesket ved poesien får et glimt af det guddommelige. Dette sker ikke gennem en logisk klar beskrivelse, men ved ord og billeder, "ssom kunne gøre emnerne kære for ham selv og det levende -medlevende - publikum» (Helge Toldberg: Grundtvigs symbolverden, 1950 (= 
HT), s. 37). Det betyder, at salmene på en gang er klare, fordi de ikke er tynget af aktuel polemik, men samtidig er dunkle, fordi de er billedtale. For at trænge ind bag billederne, må man dels gøre sig formålet med eller årsagen til brugen af dem klar og dels søge støtte til tolkningen i de tekster, hvor Grundtvig har skrevet sig til klarhed over det, han forkynder i sine salmer. Til det sidste kan samtidige prædikener ofte være en støtte.

\section{Forudsætninger}

Brugen af billeder har en teologisk og erkendelsesteoretisk forklaring. Mennesket er skabt som et fuldbårent, men ikke fuldkomment væsen: mennesket skal forklares, dvs. bringes til at indse og anerkende, at Gud er Gud. Mennesket forklares ved ordet, men det menneskelige ord er fordærvet og derfor tvetydigt. I billedsproget, som taler til følelsen, er det imidlertid muligt at vække og forklare den gudbilledrest, som ikke blev tabt ved syndefaldet. Disse tanker udformes 1810-20, og de er grundvolden for Grundtvigs poetiske virksomhed. Baggrunden for disse tanker er hans historiesyn og hans verdensanskuelse.

Historien er forklarelsens tid for menneskeheden fra skabelsen til tusindårsriget $\mathrm{g}$ for det enkelte menneske fra vugge til grav. Det betyder, at hvert slægtled har mulighed for at nå større indsigt $\mathrm{i}$ Guds skaberhensigt end det forrige, men ingen vil dog opnå fuldkommen forklarelse, før de står ansigt til ansigt med Gud. Den tid, vi lever i, er i sig selv en hindring for at nå forklarelsen. Vi kan kun gennemskue billederne i salmerne med den klarhed, som vi selv og menneskeslægten er kommet til. Med den mageløse opdagelse mente Grundtvig, at han havde oplevet det vendepunkt i frelseshistorien, hvor det menneskelige ord med Guds Ånd kunne blive entydigt igen: Ordet blev »Liv og Aand«. Når ordet er »Liv og Aand«, er det ikke længere tvetydigt eller billede på noget, men er selv, hvad det udsiger. Dette er een tolkningsnøgle til Grundtvigs salmer.

Grundtvigs verdensanskuelse hviler på skellet mellem det synlige og det usynlige. Gud og det guddommelige ved mennesket og verden er usynligt. Det synlige er ligedannet med det usynlige som 
billeder af Gud. Hele verden er i udseende og virkemåde et billede af Gud, fordi Gud ved skabelsen har præget verden og sat den igang, og fordi Gud stadig virker i den. Gudbilledet åbenbares for mennesker, når de indser, hvorledes gudbilledet i det små er ligedannet med Guds usynlige virkelighed, som på alle måder er større end billedet. På grund af syndefaldet er det synlige kun tilsyneladende, hvad det giver indtryk af. Men ved det beåndede ord, ved poesi, kan der gives glimt af gudbilledet og den guddommelige hensigt med det synlige. At ordet bliver entydigt, får afgørende betydning for verdensanskuelsen. Ordet med liv og Ånd gennembryder skellet mellem det usynlige og det synlige. Dette sker efter Grundtvigs mening ved dåben og nadveren. Korstegnelsen, vandøsningen og uddelingen af Kristi legeme og blod er for øjet billeder på Guds handlen med mennesker. Men disse billeder er så ligedannede med Guds virkelige gerning, at de ved ordets oplysning for hjertet bliver en åbenbaring af Guds gerning i verden lige nu.

Grundtvig bruger billeder, fordi de er erkendelsesskabende. Det guddommelige åbenbares for skjalden i billedsyner, som må formidles i billedsproget. Det erkendelsesskabende ved billedet er ligheden mellem det anskuede og den, der anskuer. Hvor mennesket genkender noget af sig selv i billedet, erkender det sin afhængighed af billedets ophav. Denne genkendelse kan opleves i naturen og hos hedninger, der taler sandt om menneskelivet, men den opleves stærkest, når ordet med Guds Ånd gennembryder skellet mellem synligt og usynligt.

\section{Metoden}

Som poesi er salmerne efter Grundtvigs egen mening det klareste udtryk for hans teologi, men som billedsprog er de dunkle. Da der også efter Grundtvigs opfattelse ligger noget fælles bag billederne, er det rimeligt at undersøge dette ved systematisk at sammenholde de billeder, der kan betragtes som variationer over samme tema for derved at pejle sig ind på det billedsyn, der ligger bag og dets eventuelt konstante indhold.

Ved at gøre et enkelt ord til grundtema, indsamle det i alle dets variationer og ved at analysere dem både i deres indbyrdes forhold, 
således som de fremtræder i billedsproget, og for teologisk ind hold, kan man nå frem til ordets univers, dets hovedindhold og grundforhold til andre ord: hvilket vil sige en grundtvigsk bestemmelse, som er sammenstykket på Grundtvigs betingelser. Metoden er i første omgang rent mekanisk og deskriptiv. Men ved at sammenligne de fremkomne mønstre med samtidige prædikener, med historiesynet og med verdensanskuelsen belyser teksterne gensidigt hinanden og giver større sikkerhed i tolkningen. Denne tolkning af Grundtvig ved Grundt vig betyder ikke, at det så kun kan forstås af Grundtvig. Alle Grundtvigs tekster ønsker at få nogen i tale, og om han kan få os i tale afhænger af, om vi kan genkende hans problemer som vore både menneskeligt og kristeligt.

Man kan spørge, hvorfor der ikke er anvendt en almindelig litteraturkritisk metode. Hertil må der først siges, at en sådan "almindelig « ikke findes. En egent lig metode til tekstbeskrivelse er udformet af Peter Brask i Tekst og tolkning 1973, som netop anvender sin metode på Grundtvigs "Påskeliljen» og "De Levendes Land». Ved at sætte det almentilgængelige som kriterium for et digts væidi befinder han sig i overensstemmelse med Grundtvig. Når han alligevel ud fra dette krav underkender "Påskeliljen", bunder det i en forskellig opfattelse af, hvori det almene ligger. Brask ser det i det genkendelige billedes logiske ind hold, hvorimod Grundtvig så det $\mathrm{i}$ det genkendelige billedes kare indhold. Brask er klar over, at Grundtvig fremhæver følelsen, men han kan ikke acceptere den som en almen forudsætning for erkendelse. Da denne metode ville tilsløre Grundtvigs særlige ærinde, kunne den ikke bruges.

\section{Hjertemønstret}

I Sang-Varket er hjertet et udtryk for hele mennesket, et billede på det inderste i mennesket eller menneskets selv. Det er for dette, at poesiens billeder skal gøres kære, så talen om hjertet bliver en tale til hjertet. Ordet "hjerte» forekommer 1723 gange i de 1626 salmer og er sammen med "Ordet« og "Ånden« et af de hyppigst forekommende ord. Stående overfor Gud er det hjertets gudbilledlighed, der røres og vækkes. Det er karakteristisk for de sammenhænge, 
ordet indgår i, at hjertet tager del i et dynamisk forløb som modtager og gengiver af ordet.

Hjertets modtagende og gengivende egenskaber beskrives, hvor Guds ord til hjertet bliver et genlydsord fra hjertet, eller hvor hjertet er et "Himmel-Speil i Mulde" (IV 78,5). Hjertet modtager "lys" og "lyd " og kan afhængigt af, hvordan hjertet er vendt, kaste genlyden og det måske matte lys tilbage, hvorfra det kom. For Grundtvig bliver kvinden som moder det klareste og det virkeligt levende billede på at modtage og give igen. Men billedet af hjertet som spejl rummer mere end det at kunne tilbagekaste lysstråler af det sande lys. I spejlet dannes der jo samtidigt et billede som giver spejlet lighed med den genstand, det rettes mod. Således præges hjertet både af det lys og den lyd, det modtager og gengiver.

Med sine modtagende og gengivende egenskaber er hjertet åbent for Guds ord. Men i sin stadige åbenhed underlægges det forskellige kræfter, ikke alene Guds Ånd, men også djævelens og menneskets egen ånd. De to sidstnævnte ånder er kræfter, som drager hjertet bort fra den hovedkraftlinie fra skabelsen til herliggørelsen, som hjertet vil eller bør følge. Hjertets forhold til denne hovedlinie bestemmes af dets stilling til tre faste størrelser: Gud, hjernen og verden. Dette er hovedmønstret i det undersøgte materiale.

\section{Gudbilledligheden}

Hjertets gudbilledlighed har to sider. Gud dannede mennesket i sit billede, så hjertet var åbent for ånd og egnet til at tage imod Ordet og at svare med en genlyd af det. Og Gud åndede sit billede uudsletteligt ind i hjertedybet, hvorfra det uophørligt skulle minde mennesket om skabelseshensigten: at blive Gud lig. Kun i en samvirken mellem hjertets egenskaber og mindet $\mathrm{i}$ hjertedybet kan hjertets gudbilledlighed glimtvis komme tilsyne. Men hjertet er af kød, og i sin egenrådighed forhærder det sig og forhindrer derved den samvirken, der er nødvendig for gudbilledets åbenbaring og forklarelse.

Gudbilledet er en gåde for mennesket. Det var det ved skabelsen, det er det ved genskabelsen, og det forbliver det indtil herliggørel- 
sen. Når gudbilledet glimtvis åbenbares, kalder Grundtvig det en forklarelse. Dermed mener han, at der sker en klaring af gåden. Det drejer sig både om en klaring af gådens ordlyd og om dens løsning. Gådens ordlyd er for Grundtvig: Guds kærlighed. Denne gåde løses ved at leve menneskeligt og kristeligt i kærlighed, men den bliver først endelig løst af Gud selv, når alt usynligt bliver synligt.

Denne afhandling er ikke en opskrift på, hvordan og hvorledes man kan få hjertets gudbilledlighed til at virke, som den skematiske opstilling måske kan give indtryk af. Det er derimod en systematisk fremstilling af, hvordan Grundtvig tydede og tolkede Guds virke idag. Tilknytningsstedet for dette virke er hjertets gudbilledlighed. I billedsproget nutidiggør Grundtvig Guds virke. Han forklarer menneskets genskabelse i den første skabelses ord og billeder, han beskriver Helligåndens komme i dag som en ny inkarnation, og han taler i opstandelsens og himmelfartens sprog om åbenbaringen af Kristus idag. Disse tre guddommelige handlinger indgår hos Grundtvig i eet billede af den treenige Guds vekselvirken med hjertet ved Ordet.

\section{Hjertet idag}

Idag bruges ordet hjerte næsten udelukkende om det fysiske hjerte. I overført betydning som sæde for menneskets tanker og følelser har det en plads i den litterære traditions kærlighedslyrik og i poptekster. Det kan næppe findes som et vigtigt begreb i en moderne dogmatik og er vel fagteologisk et tomt begreb. I den folkekirkelige gudstjeneste overlever det imidlertid både i prædikener og i K ingos, Brorsons og Grundtvigs salmer.

Grundtvigs fremhævelse af hjertet er en del af hans opgør med rationalismen, hvor han hævder følelsens betydning for erkendelsen. Et tilsvarende opgør kom til udtryk i ungdomsoprørets kritik af den positivistiske videnskabsteori, hvor man pegede på det politiske moment som et følelsesbetinget led i erkendelsen.

Der har i de sidste år været en opblomstring af følelsesladet Jesus-sværmeri og gurudyrkelse. På arbejdsmarkedet sættes trivsel, det at føle sig godt tilpas ved arbejdet, på linie med krav om lønforhøjelse. Kvinde- og mandebevægelserne offentliggør intimsfæren 
ved at fortælle om deres private følelsesoplevelser. Hvor andre genkender disse oplevelser, bliver de ikke mere private, men almene. Dette er reaktioner på en generel undertrykkelse af følelser både i samfundet og i kirken.

Grundtvig så følelsens og dermed også troens uomgængelige betydning for menneskets tankegang og handlinger, ja han regnede følelsen for den vigtigste grund. Med støtte især fra Johannesevangeliet skaber han en enhed mellem følelse og erkendelse som det bærende i kristendommen.

Arbejdet med Grundtvigs hjertebegreb har gjort det indlysende, at der igen må tales teologisk om følelser. Ikke fordi det netop vil tale befriende til de mennesker, der lider under fortielsen og afvisningen af deres følelser, men fordi mennesket er et følende væsen, hvis følelser indgår aktivt $\mathrm{i}$ dets tanker og handlinger, og især fordi en følelsestom kristendom aldrig har været og aldrig kan være et glædeligt budskab om Guds kærlighed til mennesker, for "med hjertet tror man til retfærdighed og med munden bekender man til frelse (Romerbrevet 10,10). Hvordan så følelsen idag kan inddrages i det teologiske arbejde ligger udenfor denne afhandlings rammer.

\title{
Billedet af Guds skaberkraft og hensigt
}

\author{
I sit eget Billed Gud \\ Skabde Mand af Mulde; \\ Elske ømt sit Hjerteskud \\ Mon ei Roden skulde!
}

$$
\text { V 79,5 }
$$

Forholdet mellem Gud og mennesket er i sin grund et kærligt faderbarn-forhold, et hjerteforhold. Mennesket er i slægt med Gud, skabt ved Guds kraft til at ligne Gud, spædt ved skabelsen og fuldkomment i saliggørelsen. Gudbilledligheden er det afgørende i forholdet mellem Gud og mennesket, men den er formørket af syndefaldet. Derfor må man kende syndefaldets virkninger, før gudbilledet nærmere kan bestemmes. 
Formørket blev ved Syndefald

Guds Billed trindt,

Blev Øret tunghørt for Guds Kald

Og Øiet blindt,

Og Tungen blev en Stamihak

Om Aand og Liv, til Bøn og Tak,

Vort Liv i Aanden blev en Ruus,

Vort Hjerte blev et Skiøge-Huus,

Vor Sjæl en selvklog Daare!

V 138,9

Syndefaldets tegn er de modsatte af Gudsrigets, som kendes fra Jesu liv blandt skøger og uforstandige, hvor han helbredte døve, blinde og stumme. Hjertets modtagelighed gennem øret og øjet og dets udtryksmiddel, tungen, er invaliderede under synden. Hjertet kan ikke længere sanse Guds kalden eller svare med hans And. I Verdens Krøniken 1814 beskriver Grundtvig syndefaldet i flere trin med omfattende betydning for muligheden af at sanse virkeligheden, som det var muligt i paradiset. Ved syndefaldet invalideredes sanserne, og talen blev til en hakken og stammen. Ved syndfloden formørkedes hensigten med hele skabelsen, og ved babelstårnet forvirredes sproget, i hvilket det sansede beskrives.

Disse syndefald dannede en tåge mellem hjertet og virkeligheden, sandheden eller Guds hensigt med skabelsen, igennem hvilken kun profeten eller skjalden kunne skue. Skjaldens billedsyner uklare billeder af virkeligheden -, som ikke kunne ses af en formørket sans, formidles til andre gennem billedsproget, der trods syndefaldets virkninger kunne rumme et glimt af virkeligheden eller et gran af sandhed. Af disse glimt og gran kan hjertet så erkende stykke for stykke, indtil det skal skue fuldt og helt, når det herliggøres.

Under synden bliver gudbilledet som en gåde umulig at løse. Alligevel må man søge dær, hvor det nok er sværest at finde, fordi Grundtvig netop mod sin samtid hævdede bevarelsen af en gudbilledrest efter syndefaldet. Gudbilledets bevarelse er et hovedpunkt i Grundtvigs kamp mod ortodoksien og et kernepunkt i hans egen teologi.

Ei gik ved noget Syndefald

Det Billed tabt, 
Hvori Guds-Barnet med Guds Kald

Var tænkt og skabt

Thi ellers, det er soleklart

Vi var ei meer af Adams Art,

Vi havde da, som Markens Dyr

End ei om Gud et Æventyr

Og ei et Ord at mæle!

Og om til os da kom Guds Ord Med Fader-Røst,

Det fandt ei Hjerte meer paa Jord, Som savned Trøst,

Det fandt ei Øre, Skiel og Skiøn,

For Ord om Aand og Tro og Bøn,

Det fandt for Mand, det fandt for Viv

Ei Længsel efter evigt Liv

Det giæsted os forgæves!

$$
\text { V } 138,7-8
$$

Var gudbilledet tabt, da var vi ikke mennesker mere, dvs. Guds døtre og sønner, som kunne mindes Gud i eventyr, høre hans ord, når han kom igen og længes efter et liv med ham.

I Grundtvigs skabelsessalmer står Adam som "Ordføreren", hvilket tyder på, at det alene er ordet i menneskets mund, der er udtryk for gudbilledligheden. Mennesket skabtes som et genlydsord.

I Begyndelsen var Ordet

Var guddommeligt hos, Gud

Gik med Aandens Kraft omgjordet

I Guds Røst fra Hjertet ud, Skabde alt med Guddoms-Evne

I det Høie paa det Jævne

Skabde Lys og Liv forvist

Gienlyds-Ordet allersidst

I sit eget Billed!

Skaberordet udgår fra Guds hjerte, derfor er mennesket også her 
et hjerteskud (se her s. 71), men gudbilledet knyttes i nærværende strofe til genlydsordet. Med genlydsordet mener Grundtvig ikke evnen til at tale, men evnen til at høre Guds Ord, dvs. at lade hjertet bevæge af Ånden deri og lade den samme Ånd med genlyd fra hjertet fare ud gennem munden tilbage til Gud.

Hvis genlydsordet er gudbilledets egentlige udtryk, må det være bevaret under synden. I anden strofe af V 193 skildres genlydsordets afhængighed af Guds eget ord, hans søn. Derpå skildres i tredje strofe syndefaldet. I vildfarelsen er der to muligheder for genlydsordet: det kan fæste sig til et dunkelt minde, og det kan blive "en Bold for alle Vinde", hvilket vil sige, at genlydsordet ikke kan være det egentlige udtryk for gudbilledet, som netop skulle bevares. Som en bold for alle vinde bliver genlydsordet styret af menneskets egen ånd eller djævelens ånd og kan som sådan ikke være et udtryk for gudbilledet, med mindre Grundtvig tænker sig flere gudbilleder, f.eks. et formalt og et materielt. Der er noget i Grundtvigs beskrivelse, som tyder derpå, f.eks. her om genlydsordet, men Grundtvig ville aldrig bruge et eksegetisk logisk skema til at forklare gudbilledet. For ham er gudbilledet levende. Når mennesket ser Guds åbenbaring, hører Guds Ord og svarer af hjertens grund, da forklares gudbilledet stykkevis i sine virkninger. Genlydsordet er før syndefaldet og efter genskabelsen et sandt udtryk for menneskets gudbilledlighed. Under synden bevares evnen til at tale, men det er ikke den, der knyttes til ved, når Gud genskaber det på een gang skabte. Når Grundtvig ved genskabelsen vil pege på gudbilledresten, bruger han en række ord: spor, gnist, billede, skygge, minde, glød og solegran. Det fælles for disse ord er, at de alle kun findes som en virkning af noget andet. De er alle fremkommet ved skabelsen, og som forudsætning for genskabelsen er de udtryk for det, som er bevaret. I hjertedybet findes det dunkle minde, genlydsordet måtte fæste sig ved, hvis det ikke skulle blive en bold for alle vinde. Det findes dog ikke $i$ os som noget, der lå under vor vilje og herredømme, men hos os.

I os selv er intet Godt

Hos os dog en Smule

Som det dybe Hjertesuk

Fra en Røverkule, 
I hjertedybet findes et skabelsesindtryk af at have stået overfor Gud før syndefaldet. Et indtryk af skabelseshensigten, hvis mål er forklarelsen. Et dunkelt minde om Guds røst, som kan genkendes ved genskabelsen. Dette grundindtryk, som præger hjertet for livet, er det gudbillede, hvis stadige udtryk er hjertets suk efter og længsel mod Gud. Men kun hvor hjertets længsel eller attrå møder det ord, som udtrykker Guds vilje, forklares gudbilledet i hjertedybet, og liv fødes.

Dette møde er grundlæggende for Grundtvig, men først 1862-63 bliver det model for en skabelsessalme: "Adam og Eva" (V 243), hvor manden og kvinden er de sanselige billeder på Ånden og hjertet:

De højbaarne unge

Guds-Billedet saae

I Ordet paa Tunge

Og Hjertets Attraa,

Og Lilievaanden, Hun følte Livs-Aanden

Opilde sin Barm!

Da sagde Guds-Manden,

Da svared hans Viv:

Vi elsker hinanden,

Det kalder vi $L i v$,

Vor Skaber til Ære,

Hans Billed vi bære,

Det kalder vi Dyd!

Hjertets trang - hunger, banken, lyst - kommer til udtryk, når det længes - higer, attrår, begærer, søger, kræver. Dette udtryk bevares under synden, men er ikke upåvirket af den. I Nordens Mytologi fra 1832 godtager Grundtvig, at »Naturalisten« kalder syndefaldet en "Aberration" (en "Udskeielse fra den naturlige Bane«). Hvor hjertets længsel ikke styres af Guds Ånd og ord, afviger den fra sin naturlige bane mod andre mål, mod verden. Bliver hjertets længsel til et begær efter verden, kan samvittigheden (se her s. 83) minde den om dens naturlige bane, men den kan ikke lede den tilbage. Det er menneskets fortvivlede situation under synden. 
Grundtvigs teologi er nøje forbundet med hans egne oplevelser og erfaringer, ja, med hele hans liv. På Langeland oplevede han gennem forelskelsen en "Trang til Liv“, som vakte en anelse om det evige os den mere end halvt rationalistiske teolog. Denne for ham uforklarlige higen udover det synlige har stadig gyldighed for ham under og efter opvækkelsen 1810-11.

Denne higen indgår som et vigtigt led i hele Grundtvigs tilværelsesforståelse i disse år og som det bærende i hans poesiopfattelse fra 1805 til ca. 1815. En undersøgelse af en række udkast om poesi fra 1816-17 viser, at opfattelsen fra 1805 om alt det skabtes præg af gudbilledet stadig findes. Sproget, der i 1805 var en hindring, er blevet et afgørende led i helheden. Dengang hed det: "Alt, hvad som bær Præg af det Evige, er Poesi«; nu skriver Grundtvig: "Al Poesi er en Aabenbarelse af Guddommen«. Grundtvigs opfattelse af det evige dengang er forskellig fra hans forestilling om Guddommen nu, men dengang som nu udtrykker poesien det gudd ommeliges billede. Poesiopfattelsens stærke tilknytning til historien sætter et dynamisk præg på dens formidler; han er ikke »poet, men profet $\mathrm{i}$ dette ords gltestamentlige forstand « (HT, s. 221). Toldberg har i sin bog redegjort for denne profets opgave; han skal ikke tyde synerne, men i tilknytninger til det kendte og kære forjætte om det, der anedes bag synet. I 1824 afklares hjertets længsel i "Jeg kender et Land " (III 86). De tre første vers handler om indtrykket af det forjættede land, og andet vers slutter:

Hvert Menneske søger med Længsel i Bryst Din smilende Kyst!

De tre næste vers indeholder længslens falske opfyldelse idrømme. I vers 7 og 8 rækker Gud sin hånd ud og åbner sin favn i Kristi navn. Dermed bliver gudbilledets udtryk ikke længere en længsel mod det, der er fjernt, men en tro på det, der med Kristus er nært (vers 9). Heraf genfødes håbet og kærligheden som nye og andre udtryk (vers 10 og 11). I 1837 kan hele tankegangen udtrykkes poetisk i et vers:

Støv-Hjertets Løndom stor,

Dets Nød i Mørkets Fængsel,

Guds dybe Finger-Spor, 
Dets underlige Længsel
Dets Tro og Lue-Daab,
Dets igienfødte Haab,
Dets Smeltning ved Guds Naade,
Med hele Livets Gaade,
Det kommer for en Dag,
I lydt Mund-Harpeslag!

I 135,3

Det gudbilledlige i længslen ligger i dens oprindelige retning og mål. Den eneste entydige bestemmelse af gudbilledet, man finder hos Grundtvig, er imidlertid Jesus som »Gud-Billedet«. Ved skabelsen satte Gud med det sande gudbillede, Guds Ord, sit præg på mennesket. Ved syndefaldet blev mennesket adskilt fra Gud, og først når mennesket atter møder sin prægeform, kan det dunkle gudbillede virkelig oplyses og længslens oprindelige retning åbenbares. Ved mødet bliver gudbilledet fuldbårent som ved skabelsen for nu som delagtig i det åbenbarede gudbillede mere og mere at udfyldes af det. Hjertets længsel hos mennesker er billede på den kærlighed, Gud skænker os. Derfor er Kristus det sande gudbillede. Thi således elskede Gud verden, at han gav sin søn den eenbårne ... (Johs. 3,16).

\section{Det åbenbarede gudbillede}

I det ord, der blev kød, åbenbaredes, hvad Guds hjerte vil, dvs. skabelseshensigten. Derfor er Jesus både gudbillede og forbillede, og dermed er han bindeled mellem Gud og mennesker. Mennesket er skabt ved ham og skal frelses ved ham. Kristus er den åbenbarede Gud, og da mennesket kun kan opfatte det åndelige ved noget legemligt, udvirkes menneskets forhold til Gud i forholdet til Kristus.

Med Jesus gentages den første menneskeskabelse; han er den anden Adam, som ikke skal falde, men tværtimod oprejse menneskelivet, så hensigten med gudsmennesket kan opfyldes. Hos Jesus er gudbilledet ikke skjult i hjertedybet, fordi han, der er uden synd, er hjerte-ren (V 256,2). Hensigten med gudsmennesket er at virke $\mathrm{i}$ 
overensstemmelse med Gud. Derfor er det i ord og gerning, gudbilledet åbenbares hos Jesus, til oplysning for mennesker.

Overensstemmelsen mellem Gud og Jesus udtrykkes med hjertebegrebet. Med henvisning til Esajas 17 bliver Jesus Guds hjerteskud. Men det er ejendommeligt, at Guds hjerteskud på en gang betegner Jesus som menneske, fordi alle mennesker er Guds hjerteskud, og samtidig betegner Jesu fulde overensstemmelse med Gud og derfor sand Gud. Forskellen mellem Jesus og andre mennesker er den, at Jesus var Guds eenbårne. Som det syndfri menneske kaldes Jesus hjerte-ren.

Jesus havde et hjerte som alle skabte mennesker; men som det sande gudbillede er Guds og Jesu hjerter ens, fordi de virker ens. Ligesom Gud ynkes Jesus over mennesket i dets nød under synden. Ved helbredelser genopretter Jesus den faldne skabning. Men som sandt menneske kan han opleve, at Guds Ånd forlader ham, og da sukker hans hjerte mod Gud (V 202,3).

Jesu liv og gerning er et guddommeligt udtryk for både opfyldelse og forjættelse af Guds frelsesplan. Hans forbilledlighed har to sider: en guddommelig som forbillede på hele Guds frelsesplan - og en menneskelig som forbillede på det enkelte menneskes genskabelse. Det sidste viser Grundtvig i Jesu forhold til hans mor, hvor Maria beskrives som den anden Eva, ved hvem det skal genoprettes, som gik tabt ved syndefaldet.

Som alle andre mennesker havde Maria et gudbillede, der i mødet med Guds ord kunne klares, ja, kunne blive kød, da ordet fæstede sig i hjertedybet. Som Jesus blev undfanget hos Maria, bliver han undfanget igen. Men dette sker i det skjulte. Både Maria og mennesket kan først rigtig erfare kødpåtagelsen, når den bliver håndgribelig, nemlig ved Jesu fødsel, hvor han åbenbares for verden, for Maria som et lille barn og for mennesket i troens ord af dets egen mund. Marias glæde over barnet er den samme som menneskers glæde over åbenbarelsen af Kristus i dag.

I Jesu forhold til sin mor og til andre mennesker afspejles både hans egen og ethvert menneskes genskabelse: Ordets fæsten sig til hjertet svarer til kødpåtagelsen, I Ordet fra hjertet fødes Jesus påny med et åndeligt legeme i den opstandnes skikkelse; lidelse og død er de fælles vilkår under synden; opvækkelsen af gudbilledet hos hjertet er også en dødeopstandelse, og som håbet løfter sig mod himlen, opfor og opfarer Jesus selv. 
Hermed står Jesus som et guddommeligt udtryk for både opfyldelse og forjættelse af Guds skabervilje - som opfyldelse i sit historiske liv og som forjættelse i sit fortsatte åndelige liv i navnet (her s. 82).

Jesus i navnet eller ordet er formidler fra Gud til mennesket som gudbilledets prægeform - i sin historiske åbenbarelse ved dåben, som det vil fremgå af det følgende - og hvor Guds ord ellers lyder i Jesu navn. Men Jesus er også formidler fra mennesket til Gud i den bøn, bekendelse og lovsang, som får sin kraft af at lyde i Jesu navn.

\section{Hjertet ligedannes med Guds}

$\mathrm{O} \mathrm{Du}$, som skabde Hjerte mit,

Det dybe, underfulde,

$O$ dan det efter Hjerte dit,

Til Himmel-Speil i Mulde,

Den levende vekselvirkning er inden for pædagogikken blevet betegnet som et grundtvigsk princip; men ved at gøre den til et princip har man uvægerlig taget livet eller det levende ud af den. Den levende vekselvirkning har sin oprindelse og sit forbillede i menneskets hjertesamtale med Gud. Den kan også virke på mange andre områder, hvor det gælder om at nå til forståelse mellem mennesker. Heri ligger den levende vekselvirknings bredde eller universalitet. Men da den levende vekselvirkning er betegnelse for et resultat, et gennemlevet forløb, ud fra hvilket man nok kan slutte sig til, hvad der er sket, men ikke udtale sig om det som en årsagssammenhæng, men snarere må betegne det som et under, kan den ikke kaldes et princip.

I det følgende redegøres der for det forløb, som kendetegner den levende vekselvirkning.

Fra poesiopfattelsen, hvor billedsproget for det indre øje danner et billede, hvis lighed med »det oprindelige« rører hjertet, udvikles Grundtvigs opfattelse af identitet og ligedannethed. Menneskets ligedannethed med Gud er både forudsætning, middel og mål: 
forudsætning i gudbilledligheden, middel for den levende vekselvirkning og målet, hvor Gud bliver alt $\mathrm{i}$ alle. Men samtidig kan Grundtvig se en ligedannethed i Guds handlen med mennesker, hvilket betyder, at skabelse, genskabelse og forklarelse sker på samme måde. Ved gentagelse af den samme handling om og om igen ligedannes mennesket med Gud $i$ et stadigt vekselvirkende forhold, hvis udfald kun er sikkert, hvor hjertet er vendt mod Gud. Genskabelsen sker $\mathrm{i}$ en vekselvirkning mellem Gud og hjertet ved ordet, hvortil hjertet er egnet ved sin medskabte evne til at modtage og gengive. Denne vekselvirkning kan følges i enkeltheder, i små forløb, som tilsammen afspejler den stykkevise erkendelse eller vækstmønstret hos Grundtvig.

Det skal forinden siges, at systematiseringen i et fremadskridende forløb kan tilsløre Grundtvigs fulde enighed med Luther i, at mennesket er både retfærdig og synder. Grundtvig ser det imidlertid som sin opgave at pege på de små fremskridt og dermed på vejen frem.

Som følge af det ligedannede i Guds handlen kan vekselvirkningen beskrives $\mathrm{i}$ et forløb, hvor der peges på de forskellige udtryk, Grundtvig bruger om samme sag.

For at forstå denne vekselvirkning mellem Gud og hjertet må hjertets modtagelighed og dermed dets føleevne først nærmere forklares. Grundtvig forestiller sig, at de udvortes sanser også er udvortes modtagere, dvs. modtagere, som tager det sansede for pålydende, men som samtidig videresender deres indtryk til hjertet og hjernen, for at der kan gives udtryk for det, som er modtaget.

Hjernen kan ud fra det modtagne, som er underlagt syndens formørkelse, og alene på grundlag af det give svar, der er ligeså formørket og tvetydigt som indtrykket. Hjernen kan ikke alene komme til klaring over menneskelivet. Det er Grundtvigs egentlige anke mod rationalismen. Derfor skal hjernen samarbejde med hjertet for at bruges ret. I hjertet samles alle indtryk. Der kan de føles kødeligt, dvs. som de modtages af de ydre sanser, og åndeligt, fordi gudbilledet er hos hjertet. Og Ordet må føles, for at det kan kendes på røsten og genkendes af det ligedannede billede hos hjertet.

I salmerne kan hjertet både se og høre. Det betyder, at hjertet som andre føleorganer altid står åben for modtagelse af indtryk. Disse indtryk, der modtages af hjertet, får et særligt udtryk, alt efter 
om hjertet retter sin længsel mod himlen i glæde eller sit begær efter verden under smerte og sorg. Derfor har hjertet nøglestillingen hos mennesket.

Grundtvigs fremhævelse af det modtagende hjerte er hans udtryk for den lutherske afvisning af menneskets medarbejderskab på frelsen. Som modtagende virker hjertet efter skabelseshensigten, når det stilles til rådighed for Guds kraft og virke. Men denne villighed og åbenhed overfor Gud kan mennesket ikke selv oparbejde. Derimod er det hjertets egenrådighed, der må opgives, for at det kan modtage, hvad det er skabt til.

„Ved Hjerte forstaa vi nødvendig det følende i os, eller os selv for saavidt vi føle: modtage Indtryk..." (Danne-Virke, III, s. 254). Idéhistorisk er tanken om følelsen som menneskets vigtigste egenskab romantikkens. I kampen mod rationalismen og i mødet mellem romantik og kristendom dannes der i samspil med Grundtvigs personlige erfaringer et følelsesbegreb, hvis grundytring er den gensidige kærlighed, som modtages og gives igen. Dette bestemmer Grundtvigs opfattelse af Gud og mennesket og forholdet dem imellem.

Guds handlen med mennesket er altid en skabelse, som har sit forbillede $\mathrm{i}$ den første skabelse i 1. Moseb. 2,7: "Og Gud Herren havde dannet mennesket (af) støv af jorden, og blæst livets aande i hans næse; og mennesket blev til en levende siel«.

Gud dannede og blæste, Jesus rørte og befalede. Den samme toleddede skabelse finder Grundtvig i dåbsritualet ved korstegnelsen og vanddåben, ved nadverens uddelingsord og selve uddelingen - eller hvor evangeliet ellers rører menneskehjertet, så det omvender sig og i Jesu navn modtager Ånden.

\section{Gud dannede med hånd og finger}

I Chr. d. VI's bibel henvises der ved ordet "dannet« i 1. Moseb. 2,7 til 1. Moseb. 1,27: "Og Gud skabte mennesket i sit billede, han skabte det i Guds billede; mand og qvinde skabte han dem«. Hos Grundtvig findes en tilsvarende sammenknytning af formgivning og gudbilledet, når han taler om »Guds dybe Finger-Spor « $(\mathrm{I} 135,3)$ eller »Spor kun af Guds Høire-Haand « (I 103,17). Det siges direkte 
i IV 25,1 og 2: En engel råber: „See Guds Finger!« og peger på "Gudbilledet". Af samme salme fremgår det imidlertid, at "Guds Finger «-begrebet er mere omfattende. Guds finger ses også i »Ordets Vei med Aanden fra Slægt til Slægt«. Her tænker Grundtvig på Guds finger i historien, som fører menneskeslægten frem mod dens herliggørelse.

Det er ud fra disse to tanker om Guds finger, korstegnelsen får sin betydning. Den er Guds indgriben i det enkelte menneskes historie, et indgreb, der præger det nye gudbillede på mennesket. Når præsten korstegner barnet, letter tågen over Guds skaberhensigt for menigheden. Præstens hånd eller finger er ikke et sløret, men et klart billede af Guds skaberhensigt, som virker efter Guds ord i dåbsbefalingen. Men som det fremgår af V 74,6, er det »Herrens Aand «, der gør korsets tegn i det skjulte, og det kan kun ske ved ordet.
Kun i Kraft af Herrens Røst, For vor Pande og vort Bryst
Korset er et Himmeltegn
Under hver en Himmelegn, Udraabs-Tegn for den Guds Fred, Som i Christi Menighed Sjæl og Hjerte frydes ved!

Det er altså Ånden i ordene ved korstegnelsen, der virker og for Grundtvig særlig Balles tilføjelse til ritualet: "... til et Vidnesbyrd, at du skal tro paa den korsfæstede Herre Jesum Christum«. Helligånden, der altid er i navnet, skriver i det skjulte på hjertet. Åndens ildtunge brænder med korstegnet Jesu navn på hjertet. Således møder hjertet den prægeform, der svarer til gudbilledet i hjertedybet. Korstegnelsen er en forjættelse eller et "Himmel-Brev« på genskabelsens virkninger: tro, fred, håb og trøst, kærlighed og fryd. Den er i sin grund en forjættelse af Jesu stadige nærvær i navnet på hjertet, hvorfra Anden altid i troens ord kan fare op til Gud.

Grundtvig kan have opfattet korstegnelsen som en dæmonuddrivelse med den virkning, at hjernen nu måtte anerkende, at mennesket kun frelses ved Guds kærlighed gennem hjertet. Det lille barn ved dåben er tillidsfuldt mod det, som gives det af kærlighed. Men 
når det vokser op, vokser også synden, og synden kan helt skjule gudbilledet under hjertet og lade korstegnet forstene på det hårde, ligegyldige, kolde og syge hjerte.

Hindringen for vekselvirkningen ved ordet ligger da i hjertets hårdhed og egenrådighed. Som en sygdom hindrer den hjertet $i$ at modtage, føle og genkende, hvilket medfører, at dets udtryk i ord også bliver syge.

Synd hos os har alt besmittet, Først og værst vor Hjertegrund,

Let derfra har Vei den hittet,

Til vor Tunge i vor Mund, Spruder, som vi alle veed, Vellyst-Gift paa Kiærlighed!

Det for Guds ord afvisende hjerte, forstenet i sorg, er undergivet egenrådigheden. Det er overgivet til sine egne udtryk, der på grund af hjertesygdommen virker modsat deres bestemmelse, og til en samvittighed, der vidner om udtrykkenes egentlige bestemmelse. Men selv om gudbilledet er bevaret og samvittigheden vidner, må der en omskabelse til.

Hjertet vel maa skabes om

Naar det er forstenet,

Men til det, hvoraf det kom:

Kiød med Aand forlenet,

Hjertet og, som har bekiendt

Al sin Skyld og sig omvendt,

Er det, som fornyes!

Når hjertet er forhærdet, må det omskabes ved noget, som kan gøre indtryk på det. Det beskrives, hvor hjertet røres. At hjertet røres af ordet, Ånden eller Jesus har samme virkning. Når Jesus rørte ved mennesker, helbredte han dem (Matt. 8,3). Ordet "røre« i SangVarket har samme betydning, men betyder samtidig at sætte i bevægelse i overført og konkret betydning. Forudsætningen herfor er, at Guds ord forkyndes lydeligt, for "...Guds-Ordet maa hø- 
res,/Om Hjertet skal røres..." (V 233,9). Det ord, der kan røre hjertet, er fortællingen om Jesu offerhandling ofte udtrykt i nadverordene. $\mathrm{Ud}$ fra sin egen lidelse forstår det sørgende, hårde hjerte Jesu lidelse, bevæges deraf og forløses i gråd. Det grædende hjerte vises tilbage til omvendelse. Gråden er et udtryk for, at ishjertet er smeltet, at stenhjertet er blødt op. Det indre udtryk for det samme er hjertets ømhed. Det ømme hjerte er følsomt, åbent og letmodtagelig for indtryk og er dermed en menneskelig forudsætning for, at den vekselvirkende samtale mellem Gud og hjertet kan komme istand ved Jesu formidling. Gud dannede, korstegnede, rørte, omskabte, omvendte og opblødte hjertet, så det ikke var forstenet $\mathrm{i}$ sorg og smerte, men opløst $\mathrm{i}$ grå d over sin egen hårdhed ved Jesu offerhandling. Dette er omskabelsesinitiativet fra Gud, og dets virkning.

Det ømme hjerte befinder sig nu mellem det skjulte gudbillede i hjertedybet og det åbenbarede i korstegnet, som er levendegjort af Guds Ånd. Det hjerte, som føler sin længsels mål: det åbenbarede gudbillede - nærved, kan kun sukke mod Gud efter hans Ånd, som skal tage bolig i hele hjertet. Dette hjertesuk er ikke et krav fra Gud, som skal opfyldes, eller en automatisk virkning af Guds indgriben, men det er et udtryk for det skjulte gudbilledes længsel, som får frit løb gennem det ømme hjerte, og kun hvor egenrådigheden er helt væk, dvs. hvor mennesket helt overgiver sig til Gud, kan hjertesukket udåndes.

Et hjertesuk er en gammel betegnelse for en bøn, og for Grundtvig er hjertesukket »Fadervor«. I dåbsritualet er forbønnen og barneevangeliet Mark. 10,13-17 menighedens suk, der udløser forjættelsen, som allerede gælder menigheden, men som nu også skal gælde dåbsbarnet, hvortil det "forhielpes" med Fadervor.

Fadervor er i henvendelsen til Gud udtryk for omvendelsens virkelighed, hvilket ved dåben bekræftes med ordene: „Gud bevare din Indgang og Udgang, fra nu og til evig Tid! Amen«.

Hjertesukket Fadervor er siden, hvergang det bedes, et omvendelsesudtryk, der har sin rod i hjertedybets gudbillede og sin kraft fra dåbens korstegn. Når Fadervor lyder, er det et udtryk for, at evangeliet, Jesus eller en anden Guds åbenbarelse har rørt hjertet, så det kan virke efter sin bestemmelse fra skabelse og dåb.

Med bønnen er den første vekselvirkning gennemløbet. Det levende ved vekselvirkningen er dels den stadige gentagelse, dels dens 
skrøbelighed, dens mulige død. Her skal dens fortsatte gentagelse følges op.

\section{Gud indblæste sin ånde}

Med 1. Peter 1,3 og Romerbrevet 6,4 i dåbsritualet forjættes genfødelse til »et levende Haab» og "opstandelse med Christus». Men før dåben kan fuldbyrdes, må den fri bekendelse komme til udtryk i et ja til Gud.

Trosbekendelsen i den tilspørgende form er kernen i den åbenbare vekselvirkning mellem hjertet og Gud. Den bydende form: „Forsager du...«, "Tror du..." afslører skabelsesordene, der skaber, hvad de nævner. Den er oplysning, dvs. ren besked til hjertets blinde tro. Det er korstegnelsens forjættelse, der nu opfyldes, hvor den blinde tro forklares ved oplysningen om, hvad den skal tro på. Trosspørgsmålene klarer og forklarer det gudbillede, der blev skrevet på hjertet ved korstegnelsen og dermed også gudbilledet i hjertedybet, hvis længsel under korstegnelsen er blevet en blind tro. Denne forklarelse af hjertet sker imidlertid ikke, før der er svaret: "Ja«, og det er afgørende for Grundtvig og dåbsdebatten idag. Først i den åbenbare bekræftelse af, at skaberordet er modtaget og ikke lukket ude eller holdt nede, først da forklares gudbilledet, og troen oplyses og oplives derpå i selve då ben ved Ånden. Dåbsordene besegler, at hjertet har modtaget Ånden. I hjertekamret er troen blevet moder:

\section{Daaben finder Troen blind}

En himmelsk Barne-Stemme!

Det »Ordet« er, Guds egen Søn,

I Jesu spæde Alder,

Og Hjertets »Haab«, i Lys og Løn, Sin Gudsøn Tro ham kalder!

$$
\text { I } 137,15-16
$$

Det lille "Ja« er det sanselige udtryk for, at Guds søn efter inkarnationen ved korstegnelsen fødes igen af hjertets tro og Guds ord nu i 
et åndeligt legeme. Svaret: »Ja« er hverken en accept eller en særlig forpligtelse, men et udtryk for hjertets håb i troens ord. Hermed er håbet levende efter 1 . Peter 1,3. Samtidig oplives og opstår det skjulte gudbillede i hjertedybet, fra hvilket "stenen « jo er fjernet, så Grundtvig kan fejre jul med håbets fødsel, påske med gudbilledets opstandelse og pinse med åndsudgydelsen ved dåben.

Som han laae i Klippehulen

Ligger han i Daabens Ord,

Men om Paasken efter Julen

Staaer han op hos den, som troer

$\mathrm{Og}$ før han til Himmels farer

Sig for Hjertet aabenbarer

Som Gudsherlighedens Haab!

IV 280,9

Hå bet er det indtryk, hjertet modtager af det troens ord, i hvilket Jesus "igen« opstår og vidner for Gud.

Den genfødte har i dåben fået syndsforladelse, og tilsidst besegler fredlysningen denne, idet den forjætter om en evig fred med Gud.

Den fortsatte åndsudgydelse sker ved nadveren, og når Grundtvig igen og igen fremhæver dåb og nadver, skyldes det, at ord og handling ved vandøsningen og uddelingen ikke blot er billedord og billedhandling, for ordene skaber, hvad de nævner og er derfor sande og virkelige, idet handlingen er kraftfuld og virker i overensstemmelse med sin hensigt. Det er usvigeligt sikkert, hvor det sker i Jesu navn, og alligevel er det et under hver gang.

Men Guds Ånd udgydes også i menneskehjertet, hver gang det hører Guds ord og svarer med troens ord. Anden kommer altid til hjertet i det lydelige Guds ord, som sanses med øret og gør indtryk på hjertet. I hjertet oplives gudbilledet af Ånden, dvs. at Jesus undfanges og fødes $\mathrm{i}$ »Troens Ord «: et "Ja» - en bøn eller en lovsang - et ord, der vidner for den, der har sagt det, og for alle andre, som er åbne herfor, at det er Guds Ånd, der vidner. Dette vidnesbyrd opvækker og forklarer gudbilledet, og i menneskets "tak" herfor farer Jesus i ordet op til Gud med vidnesbyrd om dette hjertes forklarelse.

Vekselvirkningen mellem Gud og mennesker foregår altid på 
samme måde. Med udgangspunkt hos Gud formidler det åbenbarede gudbillede Guds kraft og Ånd til det skjulte gudbillede og derfra tilbage med vidnesbyrd om, at den blev modtaget.

Af denne model findes der to udgaver: en til det tillukkede hårde hjerte og en til det ømme, hvor den første udgave baner vej for den næste. Efter således at have klarlagt vekselvirkningens forløb skal det beskrives, hvordan det leves, føles og opleves.

\section{Følelses-ligheden}

I det følgende vises, hvordan der til bestemte indtryk svarer bestemte udtryk, således at der til alle hjertets følelser: trøst, glæde osv. svarer bestemte emner eller ord, som vækker eller vækkes af disse følelser.

Hjertet ser i betydningen indser, forstår, hvilket knytter til de johannæiske beskrivelser af Jesus som lys og sandhed. Og hjertet hører det, der vedkommer og berører det. Jo mere hjertet røres og indser, des mere er det oplyst af Kristus. Dette er baggrunden for den kristelige vækst.

Hjertet føler sig trøstet, når det hører løftet om opstandelsen. Det døbte menneske står stadig over for døden. Skønt døden for det genskabte menneske kun er en legemlig død, er den dog det klareste sanselige udtryk for fravær fra Gud, og vejen til Gud går ikke udenom, men igennem døden. Derfor må hjertet stadig husvales.

Når "Troens Ord" lyder fra munden, glæder hjertet sig. Gæden hos Grundtvig er altid juleglæde, dvs. glæde over Jesu fødsel dengang og nu. I julens nutid bliver hjertet et krybberum, hvor troen føder det ord, hvori Jesus igen åbenbares for verden. Denne glæde kommer til udtryk i menneskets lovsang over Jesu komme til verden, ligesom englene sang for hyrderne.

Hjertet kan nu erfare Åndens virke og føle den fred, som fredlysningen tilsiger. Fred med Gud betyder, at synderne er forladt, og at hjertet står retfærdigt for Gud, hvilket vil sige, at skabelseshensigten er opfyldt, hvorfor hjertet jubler. Men selv om Guds fred tilsiges allerede i dåben, vil den først $\mathrm{i}$ opstandelsen være helt oprettet. Derfor bliver Guds fred både begyndelse, vilkår og mål for frelsen. 
Hjertefryden er fryd over at leve under nåden. Til forskel fra andre indtryk er fryden en fællesskabsoplevelse af skabningens lovprisning. Også denne fælles fryd kan Grundtvig finde udtryk for $\mathrm{i}$ konkrete ord: "Halleluja» eller blot "Ja og Amen« er hjertets stadige og eneste svar til Gud.

Ligesom hjertet føler længsel, føler det også troen. Hvad troen er tro på, står i trosbekendelsen, men den forklares først med den kristelige vækst. Det er for Grundtvig ikke et spørgsmål om at føle en stærk eller svag tro. Det drejer sig derimod om at bekende eller være troen bekendt. Det vil sige at anerkende gudbilledet $i$ hjertet og lade det føle "Troens Ord" gennem munden. Når troen føder håbet $\mathrm{i}$ "Troens Ord", føler hjertet troens virkning. Når det sker, har hjertet håb om fortsat forklarelse - et håb, der i ordet med Jesus farer op med et budskab om hjertets tro. Hvor denne vekselvirkning mellem troens indhold, Kristus selv, og hjertet finder sted, er den et udslag af Guds kærlighed, som er Guds selvvirkende kraft og magt. Kærlighedens magt tvinger hjerter sammen - menneskers hjerter indbyrdes og menneskers med Guds, men i stedet for at undertrykke som andre magter understøtter kærligheden den svage.

For Grundtvig er den jordiske kærlighed et billede på den himmelske. Gud er kærlighed, og hvor kærligheden lever blandt mennesker, er den et billede af Guds kærlighed, som mennesket har arvet fra skabelsen.

Men hvor kan vi sært det finde,

At kun Hjertet Dig forstaaer?

Med hver Mand og med hver Kvinde

Det jo saa os daglig gaaer,

At kun det hos dem vi fatte,

Som vi elske selv og skatte!

III 114,13

Det billedlige ligger i de vilkår, kærligheden er underlagt, og i de love, den altid følger, som kendes fra menneskelig erfaring. Forskellen består i, at kærligheden hos Gud ikke hæmmes af synden, og at den hos Gud virker med langt større kraft, fordi Gud er kærlighed.

Grundtvigs originale bestemmelse af kærligheden kommer ret 
sent til udtryk i salmerne, men er en naturlig konsekvens af hans hidtidige forståelse af den.

Kiærligheden er en Vilje,
Falder i en Synders Bryst
Lettere paa Lyng end Lilje
og er altid Hjertets Lyst,
kun Guds Kiærlighed er fri,
kun i den frigøres vi
naar af den vi undertvinges!

Kærligheden er en vilje, en kraftudløsning mod selve skabelsens formål. Gud er alene fri til at elske, hvem han vil, og er ikke underlagt tvang af den gensidige kærlighed, som mennesker er. I Guds kærlighed frigøres mennesket fra synd og død, når det frivilligt lader sig undertvinge af den i tro på Gud.

Hermed bliver kærlighed roden til al skabelse, middel for skabelsens vækst og målet for det skabtes fuldkommenhed. Gudbilledet $\mathrm{i}$ hjertet er det indtryk af kærlighed, som mennesket fik ved skabelsen, og som bestandig længes efter mere kærlighed - en længsel, der dog kun indfries hos sit ophav.

Hermed kunne gudbilledet beskrives som genstanden for en kraft, der under visse omstændigheder kan påvirke, tiltrække og måske forene genstanden med sit ophav. Men det er beskrivelsen af en død kærlighed. Kærligheden er levende, og kærligheden er en gåde; dette får sit stærkeste udtryk hos Grundtvig i hans opfattelse af hjertets kvindelighed i beskrivelsen af al livs opståen.

Livet med Gud i kærlighed må leves og opleves, hvilket kun kan ske gennem hjertet og dets følelser, kendeligt i menneskets mund. Det er sammenknytningen af følelsen og dens sproglige udtryk, der adskiller Grundtvig fra samtidens følelsestro. Hjertet er i forhold til Gud tre gange henvist til ordet: 1 . når det høres, 2. når det siges for at kunne gøre indtryk på hjertet, og 3 . når dette indtryk for at kunne erfares kommer til udtryk i endnu et ord. Med hjertets bundethed til ordet har Grundtvig sat en skarp grænse mod sværmerne, men samtidig har Grundtvig ved at fremhæve ordet selv givet anledning til kun at se på dette og dermed til at glemme hjertet. 


\section{Det kvindeliges natur}

Det prægnante ved Grundtvigs opfattelse af hjertet, er det kvindelige, som det kommer til udtryk i moderbilledet. Der er af andre peget på forbindelsen mellem hjertet og kvinden, men da hovedsagelig set fra det kvindeliges side. Grundtvigs opfattelse af det kvindelige kan ikke beskrives uden i forhold til det mandlige.

Mennesket er skabt tvekønnet, 1.Moseb.1,27: „Og Gud skabte mennesket i sit billede, han skabte det i Guds billede; mand og quinde skabte han dem». Og mennesket er i Herren begge køn ifølge 1. Kor. 11,11-12: "Dog er hverken en mand uden qvinden, ei heller en qvinde uden manden i Herren. Thi ligesom qvinden er af manden, saa er og manden formedelst qvinden; men alle ting af Gud», hvilket for Grundtvig betyder, at både mennesket i Kristus og Kristus selv har hjerte og Guds Ånd. Ægteskabet mellem Ånden og hjertet er betingelsen for liv i menneskehjertet. Det er ud fra dette grundforhold, hjertets kvindelighed skal forstås.

Det kvindelige fremhæves især i prædikener til anden søndag i fasten over teksten om den kananæiske kvinde (Matt. 15,21-28). I skabelsessalmerne kan der spores en udvikling, hvor Evas skabelse tillægges større og større betydning. Fra hovedsageligt at være knyttet til syndefaldet bliver hun på linje med Adam et udtryk for gudbilledet og medstifter af menneskelivet (se her s. 75).

Evas syndefald og Marias moderskab er tilsammen forbilledet for hjertets forhold til Gud.

Helvedes listige Hjerte-Tyv

Daared den yndige Kvinde,

End dog i hendes Hjerte-Dyb

Gud kan et Herberg sig vinde,

Kvinden bragde vor Jord i Band,

Kvinden fødte vor Frelsermand,

Han gjorde det godt Altsammen!

II 4,19

Hjertets kvindelighed beskrives ved moderbilledet med ord som livmoder, skød, bryster, amme og barn. Billedet fra sædemandslignelsen af Guds ord, der som en himmelsæd befrugter hjertejorden, hører med til moderbilledet. 
Marias hjerteforhold til Jesus som forbillede på menneskets er beskrevet (se s. 78). I Sang-Varket fremhæves tillige den samaritanske kvinde et enkelt sted:

Og Nyt og Gammelt er eens for Gud,

Og Hjertet er altid en Kvinde,

Som gaaer under Aaget til Brønden ud,

Velmødt der af Livs-Kildevældet.

V 29,9

Den samaritanske kvinde møder livskilden, og den kananæiske kvinde får tilsagnet »din vilje ske«; forbindelsen mellem disse som det samlende hos Grundtvig overhovedet er kærligheden som vilje og livsårsag. Kærligheden mellem mand og kvinde er livgivende i sin opfyldelse både for dem, der oplever den, og for barnet, som er dets frugt. Dette er for Grundtvig det sanselige billede på Åndens historie og på Guds vilje. Kun hvor mødet med Gud tilsvarende erfares som et udtryk for kærligheden, skabes der sandt og evigt lys og liv i hjertet. Sådanne tanker har Grundtvig gjort sig allerede før 1820 (Dannevirke, III, s. 52 f.), men det er tanker, som først i 1860 'erne udfoldes i salmerne.

Hjertet er det skjult kvindelige hos alle mennesker. Det kan ved sine moderegenskaber modtage Guds mandlige skaberkraft, Ånden, og kan efter sin bestemmelse føde en lovsang til skaberen, den sang, Gud også vil kendes ved på den yderste dag.

\section{Hjerteligheden}

Forholdet mellem mennesket og Gud er grundet i hjerteligheden. Guds hjerte beskrives som menneskets. Guds hjerte har sorg, længes og røres af et ord ligesom menneskehjertet. Det kvindelige menneskehjerte bliver for Grundtvig et billede på den Gudsmoder, reformationen havde fjernet fra kristendommen. Denne Gudsmoder er ikke en ny Gud, men er det kvindelige, den forbarmende egenskab hos Gud.

For enhver af os Marie

Er som Eva Moder kiær, 
Hendes Tro, vi ei fortie,

Troens Modernavn er værd,

Men ei Troen, kun Guds Naade,

Som Guds-Kiærlighedens Gaade,

Er Guds-Moderen paa Jord!

V 197,3

Nåden - Guds ømhed og barmhjertighed - er Gudsmoderen, og den er fra 1853 kvindelig i »Naaden hun er af Kongeblod “ (IV 297). Når nåden i denne salme skal forklares, er det ved hjertets forbarmende egenskab:

Ligne vor Fader eiegod, Som sig af Hjertet forbarmer, Som, naar vi falde Ham til Fod, Inderlig rørt os omarmer, Det maae vi alle i det Smaa, Det kan vi alle godt forstaae, Som har et Menneske-Hjerte!

Dertil os hjelper Naadens Aand, IV 297,6 og 7

I sin forbarmende egenskab er menneskehjertet i det små et udtryk for, hvad Guds hjerte er i det store. Så stor og stærk er Guds nåde, at den slår over fra modtagen til handlen, ligesom ordet fødes, når det er ret modtaget.

Gud tager verden til nåde og udøser sin Ånd over den. Det modtagende og gengivende er gudbilledets udtryk; men som menneskehjertets egenskaber er de ikke i sig selv retningsbestemte. Det er først mellem det skjulte gudbillede i hjertedybet og det åbenbarede i Guds ord, at de modtagende og gengivende egenskaber kan udvirke en gensidig påvirkning mellem mennesket og Gud med forklarelsen som mål.

Opfattelsen af Gud som den personlige Gud og Fader får med det kvindelige en ny dimension og bliver til den personlige Gudmoder og Fader. Moder, når Gud forbarmer sig over mennesket og lader det føle nåden, og Fader, når Guds kærlige vilje sætter sigigennem. 
Derfor udtrykker hjerteligheden hos Grundtvig hele gudbilledet på jorden, for kun i den kan det skjulte gudbillede hos mennesket komme til udtryk ved ord og handling i barmhjertighed og hengivelse.

\section{Gudbilledets forklarelse}

Menneskets forhold til Gud er historisk betinget af dåben og den stadigt gentagne vekselvirkning i bøn, nadver og lovsang. Samtidig er det et billede på menneskehedens historie mellem skabelse og frelse. Gudbilledet er ved skabelsen en gåde, der først løses endeligt ved historiens ende. I en stadig forklarelsesproces nærmer mennesket sig gådens løsning, hvilket får sit udtryk i det liv og lys, der skabes i hjertet. Både liv og lys er retningsbestemte udtryk, der peger frem mod forklarelsen.

Menneskets gåde eller "det dunkle« findes som forudsætning overalt i Grundtvigs skrifter, f.eks. i indledningen til Nordens $M y$ thologi (VU, IV, s. 18). I salmerne beskrives gåden på flere måder: "og selv sig en Gaade/Guds-Mennesket var« (V 243,1), eller: „Og skiøndt os det er en Gaade,/ Smager Hjertet dog Guds Fred « (IV 266,5). Hjertets længsel, gudbilledets udtryk er en gåde for mennesket. Gåden er knyttet til Grundtvigs grundlæggende tanker om verden som synlig og usynlig og mennesket som støv og ånd, og gåden løses, når det usynlige bliver synligt og støvet bliver åndeligt. Men dette er billedligt talt. Hvad er den konkrete baggrund herfor?

Mennesket er skabt, så det "skulde udvikles til at føle og forstaae ... erkiende stykkevis, indtil han (mennesket) kunne see Ansigt til Ansigt« (VK 1814, s. 15).

Når Grundtvig taler om at forstå og erkende i denne sammenhæng, mener han livsforståelse, hvilket han ikke behøver at bestemme nærmere, fordi det er det, det drejer sig om. Den daglige brug af ordet "forståelse« i dag dækker mest over, hvordan "noget» hænger sammen, så man ud fra sin forståelse kan undgå eller opnå dette "noget» igen. Grundtvigs brug ligger nærmere det, vi kalder indsigt. Man forstår først, hvad et andet menneske betyder for een, når man mister det, når man hjælpes af det $\mathrm{i}$ nød, eller når det glæder sig på ens vegne. Derom kan der ikke gøres prøve. Det må 
derimod stå sin prøve i virkeligheden akkurat som menneskets forhold til Gud.

At følelsen er forudsætning for forståelse, ses bl.a. af forholdet mellem hoved og hjerte. Ved syndefaldet, hvor forklarelsen ophørte, da sanserne blev formørkede, stemte hoved og hjerte ikke mere overens (II 2,27). Men ved genskabelsen indtræder hovedet og hjertet igen i det rette skabelsesforhold. Hovedet erkender og anerkender mennesket som støv og ånd, og det vil for Grundtvig sige, at hovedet anerkender, at hjertet er stedet, hvor støv og ånd mødes.

Det er imidlertid et krav, at mennesket må have noget sanseligt at erfare det åndelige igennem. Det sanselige er både hjertets længsel og det lydelige Guds ord, når de giver udtryk for gudbilledet $\mathrm{i}$ henvendelse til Gud eller i dåb og nadver, hvor Gud henvender sig til mennesker. Den levende vekselvirkning er ikke en model eller et princip for tilegnelse. Den betegner derimod et resultat, et tilbagelagt forløb, man kan slutte sig til, både når det gælder forholdet til Gud og forholdet mennesker imellem. Når mennesker er åbne for hinanden og lader den andens ord og tanker blive kød hos een selv, da kan de føle og dermed rigtigt forstå hinanden. Medfølelsen med dens åbenhed og finmærken er betingelsen for al fortåelse af noget uden for den enkelte. Medfølelse opfattes ofte kun som medlidenhed. Hos Grundtvig er medglæden lige så vigtig. I kristenlivet forklares mennesket under skiftende følelser. Under sorg og lidelse taler Jesu sorg og lidelse til hjertet. Her kom Gud mennesket imøde på menneskelige vilkår og kan derfor forstås. I glæden over den gensidige kærlighed taler Guds kærlighed til hjertet. Her mødes det guddommelige i mennesket med sit ophav.

Følelsernes ligedannethed er her afgørende for vekselvirkningen og forståelsen mellem mennesket og Gud. Kærlighedens gåde skjuler, hvoraf mennesket er skabt, og hvortil det skal fuldkommes. Men hvergang ordet møder hjertet, klares og forklares Guds viljes retning og dermed Guds kærlighed, som finder udtryk i lovsangen til skaberen.

\section{Sammenfatning af hjertets gudbilledlighed}

Hjertets gudbilledlighed er forudsætning, vilkår og mål i menne- 
skets forhold til Gud. Denne gudbilledlighed kommer til udtryk i hjertets modtagende og gengivende egenskaber og i hjertets himmerigslængsel, når mennesket forklares ved Guds ord, som det er skrevet på hjertet ved dåben, eller som det lyder til hjertet. Herved åbenbares Gud for mennesket, og i menneskets udtryk herfor i "Troens Ord» og i lovsangen åbenbares Gud i verden.

I forholdet mellem Gud og mennesket er hjertets modtagende egenskab, følelsen - bestemt af hjertets forhold til gudbilledet - den afgørende betingelse for at genoprette og vedligeholde dette forhold. Grundtvigs følelsesbegreb er dynamisk; følelsen gennemstrømmer det enkelte menneske og bygger bro til ligedannede følelser. Et sådant følelsesbegreb er fremmed for os i dag, men ikke nødvendigvis umulig i en tid, hvor følelser betragtes som noget statisk. Det er selvfølgelig historisk betinget, men ikke derfor alment på Grundtvigs tid. En sammenligning med Ingemanns statiske stemningsbilleder f.eks. (sammenhold DDS 695 med 10) fremhæver netop det dynamiske hos Grundtvig. Når hjertet modtager indtryk, føler og prøver det, om disse indtryk kan genkendes som ligedannede med gudbilledet $\mathrm{i}$ hjertedybet. Hvor det følte og genkendte får et kødeligt udtryk i det ømme hjerte, der forenes kød og ånd, hvilket føles som trøst, glæde, fred eller fryd. Men det er ikke disse følelser i hjertet, der er kendetegn i sig selv. Hjertet tør først tro og håbe på deres virkelighed, når det hører "Troens Ord" af sin egen mund til et vidnesbyrd for Gud og menneker og for hjertet selv om, at det fra skabelsen tilhører Gud og er retfærdiggiort ved dåben, at samfundet med Gud ved Jesus Kristus netop nu i et bekendende ord: en bøn, en lovsang eller et lille »Ja" opretholdes, og at det videreføres ved en stadig henvendelse til og delagtiggørelse i Guds herlighed ved Jesus Kristus i nadveren.

Det er ikke en åndelig tilfredsstillelse, der er tale om, men en kødelig og åndelig forenet følelse vekselvirkende ved det enestående bånd mellem det legemlige og åndelige: ordet.

Med gudbilledet i hjertet som genlydsmur eller som spejl, der kaster ordet tilbage som det, det var og vedblev at være i hjertet noget legemligt forlenet med Guds Ånd, lever den levende vekselvirkning helt af Guds kærligheds kraft, som hjertet skal lade sig gennemstrømme af ved en stadig omvendelse og henvendelse til Gud.

Denne henvendelse er ikke en henvendelse til en fremmed, over- 
naturlig, uigenkendelig Gud, men til den velkendte, hjemlige, kærlige Gud, som lignes bedst ved en barmhjertig mor eller en kærlig far, hvis kærlighed forstås på samme måde som menneskers, hvis sorg over menneskelivet har samme grund i synd og død, men hvis kærlighed er så ufatteligt meget større og stærkere end menneskers. Dette kan forstås teoretisk, fordi kærlighedens vilkår og love er ligedannede hos Gud og mennesker, og det kan forstås i praksis med forklarelsen af det enkelte menneske ved den levende vekselvirkning.

Det er i samspillet mellem at føle og forstå, at mennesket forklares og vokser som et lem på Kristi legeme, og denne vækst viser sig kun i menneskets stadige henvendelse til Gud.

Grundtvigs Sang-Værk er den praktiske udformning af hans teologi, som en tiltale fra Gud, en belæring om Gud og et svar til Gud. I salmerne har Grundtvig forenet sin teori og praksis således, at den samtidig er det klareste udtryk for hans teologi, ikke som et forsvar for troen eller som en forklaring af troen, men som en tale om, til og fra hjertets gudbilledlighed. 